\title{
Move beyond green building: a focus on healthy, comfortable, sustainable and aesthetical architecture
}

Article

Accepted Version

Xie, H., Clements-Croome, D. and Wang, Q. (2017) Move beyond green building: a focus on healthy, comfortable, sustainable and aesthetical architecture. Intelligent Buildings International, 9 (2). pp. 88-96. ISSN 1750-8975 doi:

https://doi.org/10.1080/17508975.2016.1139536 Available at https://centaur.reading.ac.uk/67746/

It is advisable to refer to the publisher's version if you intend to cite from the work. See Guidance on citing.

Published version at: http://dx.doi.org/10.1080/17508975.2016.1139536

To link to this article DOI: http://dx.doi.org/10.1080/17508975.2016.1139536

Publisher: Taylor \& Francis

All outputs in CentAUR are protected by Intellectual Property Rights law, including copyright law. Copyright and IPR is retained by the creators or other copyright holders. Terms and conditions for use of this material are defined in the End User Agreement.

www.reading.ac.uk/centaur 
Central Archive at the University of Reading

Reading's research outputs online 


\title{
Move beyond green building: A focus on healthy, comfortable, sustainable and aesthetical architecture
}

\author{
Hongjie Xie ${ }^{a}$, Derek Clements-Cromme ${ }^{b}$ and Qiankun Wang ${ }^{a}$ \\ a School of Civil Engineering and Architecture, Wuhan University of Technology, Wuhan 430070, \\ People's Republic of China;
}

bSchool of Construction Management and Engineering, Whiteknights, University of Reading, Reading RG6 6AW, UK

CONTACT: Hongjie Xie h.j.xie@whut.edu.cn

\begin{abstract}
The principal goal of this article is to make clear the multiple pathways through which the built environment is having a potential effect on the occupants' physical and psychological health, well-being and performance. Reviewing the previous research literature on built environment and public health, high-quality environment design is an investment as occupants are healthier, staff retention rates are higher, productivity is higher and sustainability ideals are more likely to be met. Regarding the healthy effect of built environment, a conceptual model of healthy building and a framework to research the association between built environment and health is presented and discussed. In spite of a little progress in this area by now, some genuine challenges still lie ahead: (1) the necessity of dealing with the possible health consequence of built environment; (2) the need to extend the concept and perception of green buildings towards healthy buildings and develop a framework for assessing health, well-being and productivity of various scenarios in buildings; (3) the construction and design processes needed to have a primary aim directed towards making buildings healthy for working and living in. Holistic cognition about the problem, new research method and information on scientific validation, comparative testing or data collection and analysis is needed in the subsequent research.
\end{abstract}

\section{KEYWORDS:}

Aesthetical and other specifics; beyond; green building; healthy building; research framework 


\section{Introduction}

There is nothing more important than our health and well-being. 'Health' is usually defined as 'the body is under normal conditions without disease'. However, human has the social characteristics as well as the physical characteristics. The Preamble to the Constitution of World Health Organization gave a definition of health as 'Health is a state of complete physical, mental and social well-being and not merely the absence of disease or infirmity' (WHO 1948).

In fact, it's hard to define what health is exactly. It is because of a great deal of subjectivity. Even in the absence of an obvious disease, one cannot say that the man is healthy. Different people have different sense of health or unhealthy. In general, health is a status of absence of disease, well physiological and psychological condition, happiness, comfort and well-being.

Many previous researches suggested that built environments have a direct effect on the occupants' physical and psychological health, well-being and even performance. For example, asthma and allergic diseases (Mendell et al. 2011), obesity (Bonnefoy et al. 2003), mental illness (Houtman et al. 2008), cardiovascular disease (Sandel et al. 2010; Wee et al. 2013), chronic respiratory disease (Houtman et al. 2008; Mendell et al. 2011) and cancer were seemed closely related to the indoor built environment. In other researches focused on office, evidence implied a strong causal relationship between an office's physical environment and occupant health, wellbeing and productivity (Clements-Croome 2006; WGBC 2014). Costs of ill-health are hard to compare, but the impact is clear. Poor environments contribute to absenteeism and also to people not working as well as they might which is referred to as presentism. This is an enormous cost to the UK whereas good design could save in the order of $£ 135$ billion per year by increases in productivity and reduced medical costs (Wheeler and Almeida 2006). Similar result is also in the US, absenteeism costs the employer \$2074 and \$2502 per employee per year, respectively (Labor 2010). In the school, higher ventilation rate was confirmed to improve pupils' accuracy rate and response velocity much compared with low ventilation conditions (Clements-Croome et al. 2008; Bako-Biro et al. 2012).

Over the past 20 years, the association between built environment and health, well-being and performance has attracted increasing research interest in building scientific area. But to the authors' knowledge, the mechanism how built environment impacts people's health and wellbeing is far from discovered. Until recently, there is little information available in the literature about the association between health risk factors and built environment and how they are interacting.

Today the main problem which the world is facing is energy and environment. In order to face 
the challenges of energy and resources shortage, the concept of sustainable and green building has been accepted by most of the countries worldwide. Indoor air quality, thermal comfort, lighting and noise were considered as important factors in green building criteria such as LEED, BREEM. But the point of these criteria is focus more on energy saving and resource recycling. Sometimes there is an irreconcilable conflict between meeting the requirements of energy saving and the pursuit to improve human comfort. It is necessary to emphasize health and wellbeing factors in green building. Also healthy building was put forward duly as a complement or sub-term of green building from the point of human care.

A sustainable, healthy, comfortable and safe architecture is the ultimate goal that architects and engineers have pursued for hundreds of years. After nearly a century of research and design practice in built environment, it is the time to explore the link between health, well-being and sustainability in the discussion which follows.

\section{Basic evidence of buildings affect peoples' health}

From time immemorial, built environment has incalculable implications for human health. Built environment can be divided into outdoor environment and indoor environment. Indoor air quality was concerned as a health risk factor earlier than outdoor environment. In the $100 \mathrm{BC}$, Roman architect Vitruvius began expressing concern about indoor air quality in De Architectura (Rowland and Howe 1999). Poor indoor air quality was considered as a main factor which led to disease and symptoms with the advent of the industrial revolution. The air in a building should be good and, if not, could result in diseases or at least extreme discomfort (bad smells). Ventilation thus became an important part of the indoor environment (Billings 1893).

From the late 1990s, there is a growing interest in the association between built environment and human health. Some studies have implied that the improvement of built environment has no direct link to health (Thatcher and Milner 2012). But more researchers have provided opposite evidence: good community and high-quality environment design lead to good health level because of more fresh air and more chance to participate in sports activities (Fritschi, Brown, and van Uffelen 2014). High-quality housing is also closely connected with psychological health (Evans, Wells, and Moch 2003).

Environmental health inequalities in Europe: Assessment Report pointed out that environmental health resulting from poor ratio of $14 \%$ to $54 \%$ range in different parts of Europe. Unqualified built environment in Europe leads to 10 million deaths annually. And it also leads to many avoidable diseases and injuries, including respiratory, nervous system and cardiovascular 
diseases and even cancer (WHO 2012). The main conclusion of the report is that built environment, including neighbourhood, landscape and housing condition or water supply and even accessibility and convenience to amenities are closely associated with the disease.

The Drive Toward Healthier Buildings: The Market Drivers and Impact of Building Design on Occupant Health, Well-Being and Productivity, published in the US by McGraw-Hill Construction (Bernstain and Russo 2014) in cooperation with the AIA states that $18 \%$ of home owners say doctors are their primary source of information about healthy home products and decisions - after friends, family and peers. Yet only $53 \%$ of paediatricians, $32 \%$ of GPs and $40 \%$ of psychiatrists believe buildings affect patient health. Similarly many in UK Local Authorities who control the finances do not believe school buildings have any effect on children's learning (Abdul-Wahab 2011).

In contrast to physicians the report states that $95 \%$ of homeowners believe that hospital buildings affect patient/staff health and productivity. Likewise $90 \%$ believe school buildings affect student health and productivity. In addition, $63 \%$ of the general public is aware of a link between products and practices they use at home and their health, with $50 \%$ indicating an impact on allergies and $32 \%$ pointing to an impact in asthma and respiratory illnesses. Human resource executives also recognize the link between buildings and health. Sixtysix per cent of them believe that spaces encourage social interaction, and is important when making leasing decisions (Bernstain and Russo 2013).

Based on the recent and past studies, an obvious association can be shown between building environment and health or people's performance. A community environment near highway is considered a risk factor to residents' health (Brugge, Durant, and Rioux 2007). Well-designed working place is not only beneficial to promote productivity, but also gives promotion to employee's well- being (Clements-Croome 2003, 2008, 2014). A survey on 18 primary schools in the United Kingdom proved that intervention of the housing environment (e.g. renovation and energy saving innovation) can improve the health level of students significantly (Thomson, Petticrew, and Morrison 2001). Besides this, higher ventilation rate can improve pupils' accuracy rate and response velocity compared with low ventilation conditions (Clements-Croome et al. 2008; Bako-Biro et al. 2012; Muhammad, Sapri, and Sipan. 2014). Good lighting and luminous systems also contribute to human health (Werth et al. 2013). A beautiful scenery and landscape outside the window can significantly improve employees' well-being and productivity. It is good for both our mental and physical health (Dodo et al. 2013). 


\section{Do green buildings have a better indoor environment?}

Recently green building attract more and more interesting. To green building, energy efficiency and resource recycling are unarguably important social, even planetary goals. However, seeking lighting efficiency at the expense of individuals or their organizations well-being is unlikely to succeed (Veitch et al. 2010). Therefore, energy consumption in buildings has become an essential part of all strategic lines of the EU's energy policy in terms of energy security, competitiveness together with environmental and climate respectfulness.

Does economical use of energy mean that the conditions for good well-being have to be sacrificed? With careful design a balance can be struck which ensures that buildings are healthy and enhance well-being. A research by Pelenur and Cruickshank (2013) highlighted a disconnection between well-being and domestic energy consumption and they conclude that further research is required in this area, otherwise there is a risk that national energy policies may negatively affect peoples' happiness and well-being. There is universal agreement that an integrated systemic approach to design and management is essential to attain truly sustainable architecture that is economical in the use of resources but also increases the quality of life.

A survey across Canada and the northern United States (Newsham et al. 2013) carried out a detailed study reviewing old evidence and offering new insights based on a post-occupancy evaluation of 12 green and 12 conventional office buildings. Overall they concluded that green offices tend to have better indoor environmental performance compared with conventional ones in terms of satisfaction with the environment, views, aesthetic experience, well-being including mood and physiological symptoms. The work also showed that the sustainability rating systems - in this case LEED - need further development regarding the credits allowed for some of the environmental factors.

This work echoes the findings of Miller et al. (2009), Singh et al. (2010) and Kok, Miller, and Morris (2012). Reed et al. (2011) make a comparison of rating tools which are used worldwide to evaluate how well a building stands in sustainability terms. In UK, in the BREEAM rating tool, for example, health and well-being are one of the nine categories and has a 15\% credit (Parkers 2012). Other measures of building quality include the Building Quality Assessment (BQA) (Williams 2006), the Design QuaLity Indicator (DQI) (Council 2014) and the many rating tools available such as LEED; Green Star; CASBEE; SUBET (ALwaer and Clements-Croome 2010) and others. Nevertheless how standards change, one thing is certain: Health and well-being implied an increasing weightiness in the assessments of green building. Green building should have better health-promoting properties compared to the others. 
Sustainable buildings also have potential advantages as well. According to Bernstein and Russo (2010, personal communication, McGraw-Hill Construction), US environmentally labelled buildings rent for $2-3 \%$ more and have higher staff-retention rates and decreased operating costs, and in 2008 the value of these buildings increased by 10\%. Newell (2009) quoted evidence showing that LEED- rated buildings cost $6 \%$ more to build, have staff-retention rates over $4 \%$ higher, command $2-6 \%$ higher rents and save $10-50 \%$ in energy consumption. Integrated design and management processes may reduce this extra build cost of about $6 \%$ to the point where there is no extra cost (Rehm and Ade 2013).

McGraw-Hill Construction (Bernstain and Russo 2014) states that construction industry professionals are placing increasing attention to health in design and construction plans. According to the study, firms focusing on green buildings are more attuned to health issues, and all firms questioned report an increase in addressing occupant health in design and construction.

This report shows the results for a survey of non-residential property owner's beliefs and found significant benefits from healthy buildings:

$47 \%$ a reduction in the cost of healthcare ranging from $1 \%$

to $5 \%$; $66 \%$ improved employee satisfaction;

$56 \%$ lower absenteeism;

$21 \%$ higher employee productivity.

We can concluded that high-quality environmental design is an investment as occupants are healthier, staff-retention rates are higher, productivity is higher and sustainability ideals such as lower energy consumption are more likely to be met. Second, we present a conceptual model of healthy building and a framework to research Built Environmental Health (Clements-Croome 2014).

\section{Beyondgreen building:aconceptual frameworkforunderstandingtheassociations between the built environment and health}

It seems that the word green building is overused when we emphasize energy efficiency. It is easy to understand under the background of sustainable development. But building is not only a machine for living, it also a shelter to flee away, a place to settle down soul and first of all, it should be an inhabit environment where people can gain physical and mental health, relaxation and freedom. We think the connotation of sustainable building is broad, while the meaning of green building is ambiguous. It is the time to extend the green building into healthy building 
because good health is the basement of good life, and a lack of it affects work performance

Howard has defined green building as a practice of (1) increasing the efficiency with which buildings and their sites use energy, water and materials and (2) reducing building impacts on human health and the environment, through better siting, design, construction, operation, maintenance and removal - the complete building life cycle. And according to the US Green Building Council (USGBC), green building is 'the practice of increasing the efficiency of new buildings, and reducing their impact on human health and the environment through better site location, design, construction, operation, maintenance, and removal'. In both definitions less impact on human health is one of the main features of green building. Materials which are used in green building construction process are not only environment friendly but they are also healthier and cleaner for the residents. Green buildings with exclusive features such as better ventilation, using more sunlight and higher indoor air quality provide healthier environment and increase occupants' productivity and well- being compared with non-green buildings.

To pursue a better life quality and a healthy life, we need buildings with less impact on environment and human health. As buildings occupy most of our life time, humans' well-being in the building should be taken care of. Well-being is a concept which attracts more research interest all over the world recently. Comfort is a comprehensive term and is perhaps defined and best summarized by Maslow (1943) in his theory of hierarchy of needs which cover physiological, psychological, social and personal needs. Well-being is only one aspect of mental health; other factors including personal feelings about one's competence, aspirations and degree of personal control coincide with Maslow's theory perfectly. It is connected with overall satisfaction, happiness and quality of life.

In the late 1980s, the World Health Organization identified the concept of healthy building: Free of hazardous material (e.g. lead and asbestos) and capable of promoting health and comfort of occupants throughout its entire life cycle, meeting the social needs and upgrading productivity (Barton and Grant 2008).

To the authors' knowledge of the built environment, a healthy building is not only good for physiological and psychological health, but it also promotes the occupant's well-being, providing a comfort life and upgrading productivity and performance, meet the prosperous needs of occupants in terms of efficiency energy and be responsive to the needs of uncertain changes in the future (e.g. climate change, multidimensional and multicultural society).

Figure 1 is a conceptual model for understanding the association between the built environment and health which is partly inspired by the work of Social determinants of health 
and environmental health promotion (Northridge, Sclar, and Biswas 2003). The model posits the connections between built environment, health risk factors and health outcomes and interactions with each other. Structurally, our model posits a set of simultaneous and dynamic relationships among the three domains of our model. For analytic purposes, the built environment is divided into outdoor environment and indoor environment as a basic domain. Most of our research interest is focussed on indoor environment. Healthrisk factors are presented as three fundamental factors:

(1) the socio-economic factors (including demographic information, genetic factors, economic income, life style, social and cultural factors, social support); (2) physical factors (including pollutants, CO2, ventilation rate, air velocity, temperature, relative humidity, illuminance levels, daylight, background noise); (3) physiological and design factors (including building density, ventilation system, architecture design, interior layout and furniture design, colour, biophilia and view, green material, avoid accidental harm etc.). Finally, the last column in Figure 1, Health and Well-Being, contains two domains: health outcomes include SBS, mental illness, cardiovascular diseases, obesity, respiratory health and others; well-being effects include perceived health, psychological health, life satisfaction, happiness and productivity, to name but a few. As these in turn clearly influence civic life, Figure 1 illustrates the interactive and dynamic nature of the proximate factors and health and well-being domains through the use of arrows between these levels. 


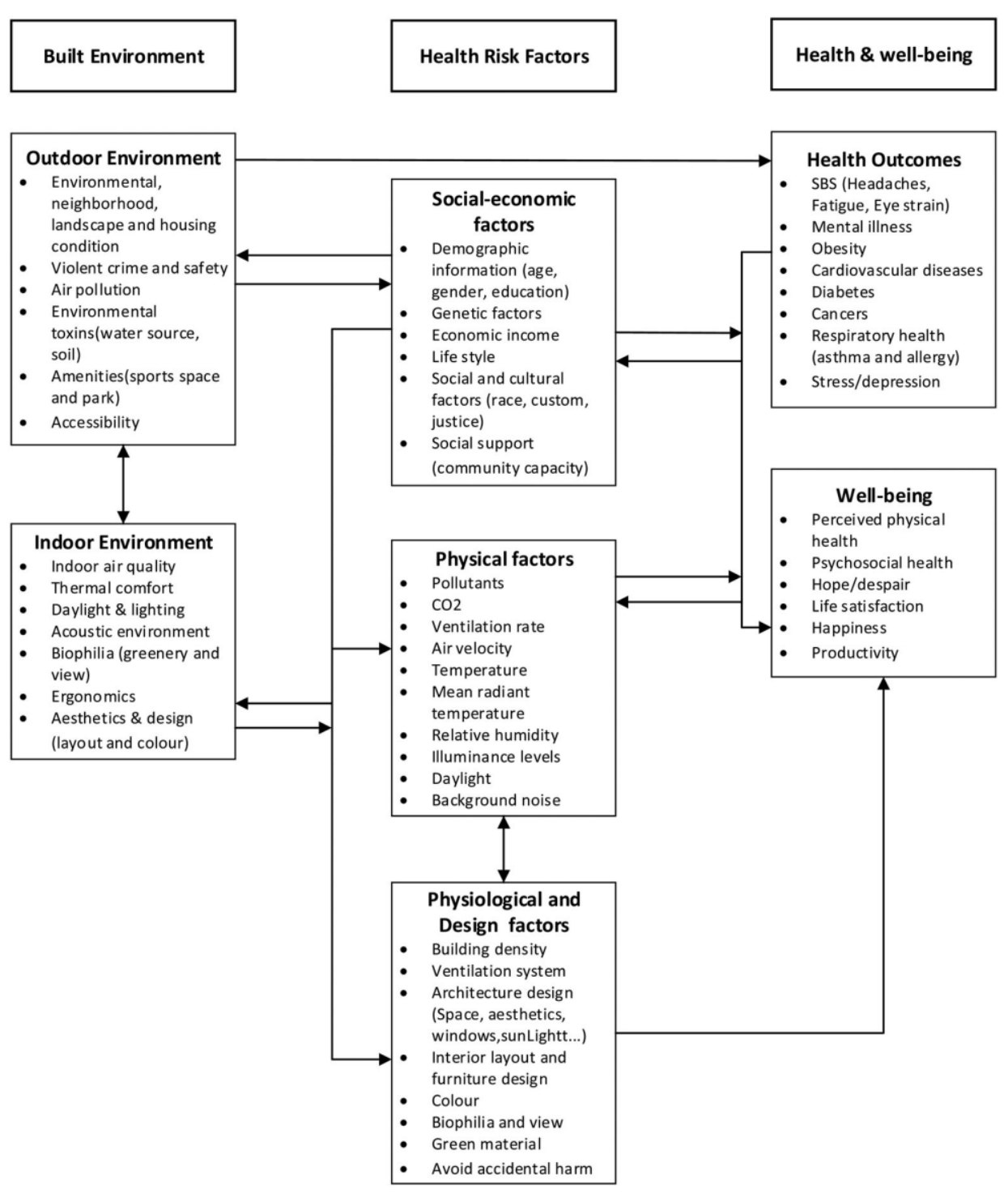

Figure 1. Model of building environment and health, well-being (for discussion).

\section{Conclusion}

Today the challenge lies in the accomplishment of healthy, comfortable, convenient and safe built environment with low energy consumption. Healthy building should be sustainable architecture in terms of responsiveness to occupants' well-being and health; low resource consumption with low pollution and waste; flexibility and adaptability to deal with change; appropriate balance of high and low technology. Balance the well-being and health with energy consumption about which no consensus should be on agenda in the future. The health building model we proposed include the building environment, health-risk factors and health and wellbeing. The three aspects influence each other and interact with each other.

Maybe the first thing is to present a hypothetical framework to research the complicated association between built environment and health. On the basis of health and building 
environment framework, a dose-response indicator at human level and building indicators system of healthy building environment can be build. So far the association between built environment and health was fuzzy and incomplete, for example, the time factors with dynamic process and interactions occurring at different levels are not taken into account, and most formal indicators and research methods are not applicable or useful. The needs of seeking new research methods and approach are urgent since the built environment is so important to people's life. Holistic cognition about the problem, new research method and information on scientific validation, comparative testing or data collection and analysis are needed in the subsequent research (Bluyssen 2010).

There is also an urgent need to create greater public awareness of the health impacts of buildings; increase the focus on better tools and methodologies to collect data and measure healthy impacts; and encourage building codes to place increased emphasis on healthier building practices. If we only concentrate on energy we are in danger of neglecting the real purpose of architecture which is to provide for people's well-being. A balance between these requirements is necessary.

The main conclusions that can be drawn from this article are:

- Building and built environment can affect our health and well-being seriously more than we can imagine. Today we only focus on energy efficiency and conservation of resources is far from enough to face the challenge of future, we must also concern about the health effects of the building. Beyond the concept of green building, a healthy, comfortable, sustainable and aesthetical architecture - healthy building should be put forward as a complement or sub-term of green building;

- Healthy building issues can be hard to define and the impact of indoor environment risk factors hard to measure. From the perspective of promoting healthy level as well as well-being of occupants rather than just the absence of disease, measuring health impact of building can be even more difficult in the future;

- From the view of a full life cycle, the excessive cost for healthy building will reward by a number of benefits. Healthy architecture and high-quality environmental design is a valuable investment as occupants are healthier, staff-retention rates are higher, productivity is higher and sustainability ideals such as lower energy consumption are more likely to have been met (Clements-Croome 2008, 2014).

- A rough research framework of healthy building can be established initially which can be divided into three parts: built environment, health-risk factors and health and well- 
being effect. In order to promote and accelerate the research, new research paradigm and new research methods that refer to other disciplines especially complex system science, bioscience and medicine are needed;

The construction and design processes need to have a primary aim directed towards making buildings healthy for working and living in. Many stakeholders need to be involved in the implementation of solutions (e.g. architects, facility manager, construction industry, building scientists, communications specialists and code officials). Collaboration of all stakeholders will likely result in sound guidelines and be more effective than regulations. 


\section{References}

Abdul-Wahab, S. A. 2011. "Sick Building Syndrome in Public Buildings and Workplaces." In The Interaction Between the Physical Environment and People, edited by D. Clements-Croome, 239-261. Berlin: SpringerVerlag.

ALwaer, H., and D. J. Clements-Croome. 2010. "Key Performance Indicators (KPIs) and Priority Setting in Using the Multi-Attribute Approach for Assessing Sustainable Intelligent Buildings." Building and Environment 45 (4): 799- 807.

Bako-Biro, Z., D. J. Clements-Croome, N. Kochhar, H. B. Awbi, and M. J. Williams. 2012. "Ventilation Rates in Schools and Pupils' Performance." Building and Environment 48: 215-223.

Barton, H., and M. Grant. 2008. "Testing Time for Sustainability and Health: Striving for Inclusive Rationality in Project Appraisal." Journal of the Royal Society for the Promotion of Health 128 (3): 130-139.

Bernstain, H., and M. Russo. 2014. "The Drive Toward Healthier Buildings: The Market Drivers and Impact of Building Design on Occupant Health, Well-Being and Productivity." McGraw-Hill Construction. http://www. armstrong.com/commceilingsna/impact-of-buildings-on-health.html.

Bernstein, H., and M. Russo. 2013. "Smart Market Report.” McGraw-Hill Construction (MHC_Analytıcs@mcgrawhill.com).

Billings, J. S. 1893. Ventilation and Heating. New York: Engineering Record.

Bluyssen, P. M. 2010. "Towards New Methods and Ways to Create Healthy and Comfortable Buildings." Building and Environment 45 (4): 808-818.

Bonnefoy, X. R., M. Braubach, B. Moissonnier, K. Monolbaev, and N. Röbbel. 2003. "Housing and Health in Europe: Preliminary Results of a Pan-European Study." American Journal of Public Health 93 (9): 1559-1563.

Brugge, D., J. L. Durant, and C. Rioux. 2007. "Near-Highway Pollutants in Motor Vehicle Exhaust: A Review of Epidemiologic Evidence of Cardiac and Pulmonary Health Risks." Environmental Health 6 (1): 23-29.

Clements-Croome, D. J. 2003. "Environmental Quality and the Productive Workplace." In Innovative Developments in Architecture, Engineering and Contruction, edited by C. J. Anumba, 335-341. Rotterdam: Millpress Science Publishers.

Clements-Croome, D. J. 2006. Creating the Productive Workplace. New York: Taylor \& Francis.

Clements-Croome, D. J. 2008. "Work Performance, Productivity and Indoor Air." Scandinavian Journal of Work Environment \& Health 34 (4): 69-78. 
Clements-Croome, D. J. 2014. "Sustainable Intelligent Buildings for Better Health, Comfort and Well-Being." DENZERO EU PROJECT Conferrence, Budpest, September 11. http://www.derekcroome.com/publications.html. Clements-Croome, D. J., H. B. Awbi, Z. Bako-Biro, N. Kochhar, and M. Williams. 2008. "Ventilation Rates in Schools."

Building and Environment 43 (3): 362-367.

Council, C. I. 2014. “Design Quality Indicator.” Accessed January 22, 2015. http://www.dqi.org.uk.

Dodo, Y. A., M. Z. Kandar, D. R. Ossen, J. D. Jibril, A. H. Bornoma, and A. I. Abubakar. 2013. "Importance of a View Window in Rating Green Office Buildings." Green Building Technologies and Materials II 689: 180-183.

Evans, G. W., N. M. Wells, and A. Moch. 2003. "Housing and Mental Health: A Review of the Evidence and a Methodological and Conceptual Critique." Journal of Social Issues 59 (3): 475-500.

Fritschi, J. O., W. J. Brown, and J. G. Z. van Uffelen. 2014. “On Your Feet: Protocol for a Randomized Controlled Trial to Compare the Effects of Pole Walking and Regular Walking on Physical and Psychosocial Health in Older Adults." BMC Public Health 14(1): 1-8.

Houtman, I., M. Douwes, T. de Jong, J. M. Meeuwsen, M. Jongen, F. Brekelmans, M. Nieboer-Op de Weegh et al. 2008. New Forms of Physical and Psychosocial Health Risks at Work. Brussels: European Parliament. https://www.researchgate.net/publication/236023823_New_Forms_of_Physical_and_Psyc hosocial_Health_Risks_at_Work.

Kok, N., N. G. Miller, and P. Morris. 2012. "The Economics of Green Retrofits." The Journal of Sustainable Real Estate 4 (1): 4-22.

Labor, U.D.O. 2010. Absences from Work of Employed Full-Time Wage and Salary. Washington, DC: US Department of Labor.

Maslow, A. H. 1943. "A Theory of Human Motivation." Psychological Review 50 (4): 370-396.

Mendell, M. J., A. G. Mirer, K. Cheung, M. Tong, and J. Douwes. 2011. "Respiratory and Allergic Health Effects of Dampness, Mold, and Dampness-Related Agents: A Review of the Epidemiologic Evidence." Environ Health Perspect 119 (6): 748-756.

Miller, N. G., D. Pogue, Q. D. Gough, and S. M. Davis. 2009. "Green Buildings and Productivity." The Journal of Sustainable Real Estate 1 (1): 65-89.

Muhammad, S., M. Sapri, and I. Sipan. 2014. “Academic Buildings and Their Influence on Students' Wellbeing in Higher Education Institutions." Social Indicators Research 115 (3): 1159-1178. 
Newsham, G. R., B. J. Birt, C. Arsenault, A. J. L. Thompson, J. A. Veitch, S. Mancini, A. D. Galasiu, B. N. Gover, I. A. Macdonald, and G. J. Burns. 2013. “Do “Green’ Buildings have Better Indoor Environments? New Evidence.” Building Research and Information 41 (4): 415-434.

Newell, G. 2009. "Developing a Socially Responsible Property Investment Index for UK Property Companies." Journal of Property Investment \& Finance 27 (5): 511-521.

Northridge, M. E., E. D. Sclar, and P. Biswas. 2003. "Sorting Out the Connections Between the Built Environment and Health: A Conceptual Framework for Navigating Pathways and Planning Healthy Cities." Journal of Urban Health- Bulletin of the New York Academy of Medicine 80 (4): 556-568.

Parkers, J. 2012. "Value of BREEAM, The (BG42/2012). London: BSRIA Inc.

Pelenur, M. J., and H. J. Cruickshank. 2013. "Investigating the Link Between Well-Being and Energy Use; An Explorative Case Study Between Passive and Active Domestic Energy Management Systems." Building and Environment 65: 26-34.

Reed, R., S. Wilkinson, A. Bilos, and K. W. Schulte. 2011. "A Comparison of International Sustainable Building Tools-An Update." The 17th Annual Pacific Rim Real Estate Society Conference, Gold Coast, Australia, January 16-19. Rehm, M., and R. Ade. 2013. "Construction Costs Comparison between Green and Conventional Office Buildings."

Building Research and Information 41 (2): 198-208.

Rowland, I. D., and T. N. Howe. 1999. Vitruvius: 'Ten Books on Architecture'. Cambridge: Cambridge University Press. Sandel, M., A. Baeder, A. Bradman, J. Hughes, C. Mitchell, R. Shaughnessy, T. K. Takaro, and D. E. Jacobs. 2010. "Housing Interventions and Control of Health-Related Chemical Agents: A Review of the Evidence." Journal of Public Health Management and Practice 16 (5): S24-S33.

Singh, A., M. Syal, S. C. Grady, and S. Korkmaz. 2010. "Effects of Green Buildings on Employee Health and Productivity." American Journal of Public Health 100 (9): 1665-1668.

Thatcher, A., and K. Milner. 2012. "The Impact of a 'Green' Building on Employees' Physical and Psychological Wellbeing." Work-A Journal Of Prevention Assessment \& Rehabilitation 41: 3816-3823.

Thomson, H., M. Petticrew, and D. Morrison. 2001. "Health Effects of Housing Improvement: Systematic Review of Intervention Studies." British Medical Journal 323 (7306): 187-190.

Veitch, J., G. Newsham, S. Mancini, and C. Arsenault. 2010. "Lighting and Office Renovation Effects on Employee and Organizational Well-Being." NRC Report IRC - RR-306. Accessed August 10, 2012. http://nparc.cisti- 
icist.nrc-cnrc. gc.ca/npsi/ctrl?action=rtdoc\&an=20374532\&article=0\&fd=pdf.

Wee, L. E., G. C. H. Koh, W. X. Yeo, R. T. Chin, J. Wong, and B. Seow. 2013. "Screening for Cardiovascular Disease Risk Factors in an Urban Low-Income Setting at Baseline and Post Intervention: A Prospective Intervention Study." European Journal of Preventive Cardiology 20 (1): 176-188.

Werth, L., A. Steidle, C. Hubschneider, J. de Boer, and K. Sedlbauer. 2013. "Psychological Evidence on Light and Its Impact on Humans - An Overview." Bauphysik 35 (3): 193-204.

WGBC. 2014. "Health, Wellbeing and Productivity in Offices: The Next Chapter for Green Building." http://www. ukgbc.org/resources/publication/health-wellbeing-and-productivity-offices-next-chapter-green-building. Wheeler, G., and A. Almeida. 2006. "These Four Walls: The Real British Office." In Creating the Productive Workplace,edited by D. Clemens-Croome, 357-377. London: Routledge.

WHO. 1948. "WHO Definnition of Health". http://www.who.int/suggestions/faq/en/.

WHO. 2012. "Environmental Health Inequalities in Europe: Assessment Report." http://www.euro.who.int/en/ publications/abstracts/environmental-health-inequalities-in-europe.-assessment-report.

Williams, B. 2006. "Building Performance: The Value Management Approach." In Creating the Productive Workplace, edited by D. Clemens-Croome, 434-458. Oxford: Rouledge-Taylor and Francis. 